\title{
Identification of Engine Damages of Vintage Vehicles with Tribological Examination
}

\author{
Cs. Papp \\ Department Engineer \\ Széchenyi István University \\ Department of Mechatronics and \\ Machine Design \\ Hungary \\ R. Kuti \\ Full Professor \\ Széchenyi István University \\ Faculty of Mechanical Engineering, \\ Informatics and Electrical Engineering \\ Hungary
}

Nowadays, keeping vintage vehicles in operation is becoming more and more popular, however, the reparation of occurring engine malfunctions, and the supply of particulate engine parts mean severe expenses to the owners. In case of older engines, the failure detection is not performed with the help of computerized diagnostics. In several cases the detection of failure is only possible with the disassembly of the engine.

A cost-effective solution may be the application of tribological examinations, with which, the malfunctions may be revealed without the needless disassembly of the engine.

The purpose of our research is to represent through the tribological examination of a VAZ-2101 (also known as Lada) engine type the practical application of the method, data analysis, evaluation of results and the steps of failure detection.

Keywords: Vintage vehicle, internal combustion engine, tribological examination, failure detection

\section{INTRODUCTION}

The operation of modern vehicles, the identification of occurring engine malfunctions and the reparation of failures are simplified with the help of computer diagnostic support. These methods are, unfortunately, not applicable in case of the operation and reparation of vintage vehicles, because these were built in a traditional way, computerized systems were not installed in vehicles.

Traditional, manual methods of failure detection shall be used before the reparation of malfunctions, which are based on the disassembly of the engine.

The disassembly of engines, in case of minor malfunctions, is also goes along with the changing of sealings and purchasing them in case of formerly manufactured vehicles is a hard and expensive task.

In order to minimize the costs, we performed tribological examinations in the point of view of engine diagnostics.

The chosen vehicle is a BA3-2101, also called Lada 1200. This car was a popular vehicle type in the socialist countries, like in Hungary as well. Although, the number of them kept in operation decreased nowadays.

Ladas, operating and possessing qualified oldtimer vehicle inspection, represent significant values. For the operation of these passenger vehicles, leaded fuels were necessary, however, these fuels are no longer available on the market in Hungary. That is the reason why our examinations deal with the effects of unleaded fuels on the engine.

Received: January 2021, Accepted: May2021

Correspondence to: Papp Csenge, Széchenyi István

University, Department of Mechatronics and Machine

Design, H-9026 Györ, Egyetem tér 1., Hungary

E-mail: papp.csenge@ga.sze.hu

doi:10.5937/fme2103608P

(C) Faculty of Mechanical Engineering, Belgrade. All rights reserved

\section{TRIBOLOGY}

A liquid state machine element is inevitable for engines increasing the lifetime, improving the operational safety and favourable energy consumption. This machine element is none other than the engine oil. This structural element is as important as other engine component. The oil, itself provides lubricaton. The task of lubrication is to minimize wear and to keep the friction coefficient on an optimal level.

Nevertheless, oil has not just lubricating functions in engines, but it also has other important tasks. Oil has a sealing function too, for instance, between the piston ring and the cylinder wall, it closes the hot, highpressure gases out. Oil is a good cooling medium as well, it transfers heat through the oil pan. It is also an anticorrosion and cleansing tasks too, so it transports the wear and residuals of combustion from the lubricating areas.

We can also mention that noises occurring in the engine are damped by the oil, so it works as a vibration damper.

\section{OWN INVESTIGATION}

Ladas represent classic automobile constructions, the engine, which is placed in the front, with the help of the intermediate cardan shaft and the differential gear, which is placed in the rear, drives the rear wheels.

This structure is typical for all classic Lada types, because the chassis, the engine, the power transmission, the running gear and the electrical equipment are fundamentally the same as in the VAZ-2101 basic type. [1]

The examined vehicle was manufactured in 1980. It is in the original state, its milage is only $37000 \mathrm{~km}$ and it is qualified as an oldtimer vehicle, shown in the next figure. 


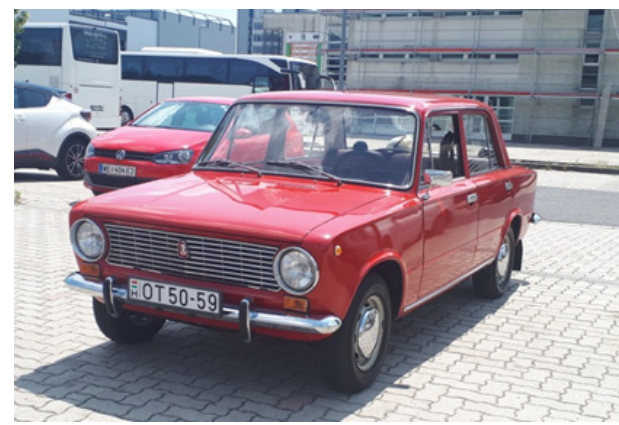

Figure 1. Lada 1200

The make (Lada 1200) refers to the displacement of the pistons which is 1200 , more accurately $1198 \mathrm{ccm}$. This is an in-line cylinder arranged, eight-valve, overhead $(\mathrm{OHC})$, chain driven, water cooled, four-stroke gasoline engine.

According to the factory specifications of Lada 1200, in the whole year $15 \mathrm{~W} 50$, in wintertime $20 \mathrm{~W} 20$, in summer 30 single grade oil should be poured into the engine. Regarding the age of the investigated vintage car, the owner used 20W50 MOL Botond type engine oil. This type of oil is suitable for gasoline passenger- and smaller commercial vehicles manufactured before 1989 .

The 20W50 specification system is the own classification system of SAE (Society of Automotive Engineers). The 20W50 oil is a multigrade oil. Its base oil is mineral oil. The kinematic viscosity of the $20 \mathrm{~W} 50$ oil used in VAZ-2101 is $17,4 \frac{\mathrm{mm}}{\mathrm{s}^{2}}$, its density on $15^{\circ} \mathrm{C}$ is $0,888 \frac{\mathrm{g}}{\mathrm{cm}^{3}} \cdot[2]$

This is a dense oil from the point of view of its state of matter, meeting the demands of the lubrication of low performance, older vehicles. The viscosity classes and the values belonging to different oil types may be found in a table published by SAE. The oil used in the Lada 1200 is a multigrade oil, which is used between -15 and $+55^{\circ} \mathrm{C}$. [3]

This engine oil is perfectly appropriate for the temperature requirements of Hungary, furthermore its kinematic viscosity is even higher. The kinematic viscosity of the $20 \mathrm{~W} 50$ oil on $100^{\circ} \mathrm{C}$ is between 16,3 and 21,9 [3].

With the increase of the temperature the internal friction of liquids decreases - that means the dynamic viscosity of material. Regarding the operation of a vintage vehicle, except during cold start, the oil with higher low temperature pumping viscosity is the optimal choice.

On the basis of the previously mentioned facts, it is obvious that oil has a key role in the operation of the engine. As a consequence, it reaches almost every component of the engine, so it takes a diagnostic role as well. It means a kind of solution to examine the oil used in the engine, since wear and pollutants refer to the conditions inside the engine and so, the location of the failure is traced back.

In the fuels tanked into the old type vehicles, lead additive was used to avoid knocking during combustion and to improve the wear resistance of valves.

Nevertheless, since the $1^{\text {st }}$ of January 2000, in Hungary and in all of the member states of European
Union, it is prohibited to distribute leaded fuel because of its effect on health and environment.

Tetraethyllead causes acute or chronic leadpoisoning due to inhalation or absorption through skin. This action caused significant problems in automotive industry, because the engines of vehicles were opti-mized to leaded fuels. Using unleaded fuels meant severe harms to engines. This problem affects vintage cars. According to factory specifications 93 octane number fuel is the proper for BA3-2101 type passenger vehicle. In the 1980's in Hungary, 92 octane fuel was available that was proper as well. Nowadays, these low octane number fuels are not available, 95, 98 and 100 octane petrols are on the market.

To have a general idea about the negative effects of unleaded fuel, the examination of the content of oil used in the engine, is necessary. This examination may mean the diagnostics in case of vintage vehicles, as a consequence, oil helps to make conclusions about the conditions in the engine.

Sampling was done from the examined, untouched BA3-2101 type engine. To the accurate conclusions wear measurement with the help of a tribometer and oil content analysis conducted in laboratory conditions were made. Wear measurement was carried out with an Optimol SRV 5 type universal tribometer. This machine is suitable for model examinations, which means the examination of coatings, in ball-disc connection, with oscillating movement. Measurements were made according to the ISO 19291:2016 [4] - Lubricants Determination of tribological quantities for oils and greases - Tribological test in the translatory oscillation apparatus standard. The machine is capable of the application of alternating, rotating and combined movements. Its maximum stroke is $5 \mathrm{~mm}$, maximum frequency is $500 \mathrm{~Hz}$. In case of rotating movement, its maximum examination radius is $45 \mathrm{~mm}$. Its maximum speed is $2000 \mathrm{rev} / \mathrm{min}$, it can heat specimen up to $350^{\circ} \mathrm{C}$. The lubrication in the tribometer is carried out with micropump, with a maximum of $800 \mathrm{ml} / \mathrm{h}$ throughput, pre-condition is maximum $150^{\circ} \mathrm{C}$. [5]

After removing the dipstick of the Lada 1200 engine, oil sample was taken with the help of a hand vacuum pump. Oil is SAE 20W50 type, ran only 1000 $\mathrm{km}$ after fill-up. As a comparisonal basis, we took sample from the same type of oil, which was in a brandnew oil bottle. Both samples were examined 3 times to have the measurement values more accurately evaluated. Measurements were made with 100 Cr6 material disc lapped and polished on its surface and a 10 $\mathrm{mm}$ diameter ball. This is the so-called ball-on-disc tribological measurement. In the first 5 minutes of the measurement, the apparatus makes pre-condition. In this phase, temperature is increased to $100^{\circ} \mathrm{C}$ and the load is 50 N. [6]

This is very important in terms of similarity of all 6 measurements, 3 by every sample, to start the measurement with similar conditions. The reproducibility of measurement conditions is crucial. After pre-condition, the machine positions and pre-running on $50 \mathrm{~Hz}$ frequency and with $1 \mathrm{~mm}$ stroke.

Since the measurement is carried out on $150 \mathrm{~N}$ load and $100^{\circ} \mathrm{C}$ temperature according to the standard, the 
further $50 \mathrm{~N}$ load is added to the $100 \mathrm{~N}$ after positioning. The velocity of oil flow is $225 \mathrm{ml} / \mathrm{h}$. The apparatus runs 2 hours and it monitors the measurement in a diagram about boundary and hydrodynamic friction.

The Optimol SRV tribometer traces two values with a built-in software during measurement. One of them is boundary friction and the other is hydrodynamic friction.

In case of boundary friction between the two friction-surfaces a very thin film forms. This film ensures some kind of lubrication in the friction system.

Figure 2 shows the values of boundary friction during measurement in case of the oil running $1000 \mathrm{~km}$. The value of boundary frictions is between $0,1 \ldots 0,5$. According to the diagram, in case of the used oil this value varies between very low values, that is 0,18 and 0,19 after pre-running, we can consider this value to be static. This means that the oil used inbetween the two specimens (ran $1000 \mathrm{~km}$ ) has lower boundary friction value, than the original-state oil $(0 \mathrm{~km})$, because in case of the new oil it varieas between 0,20-0,255. According to the value for boundary frition, the measurements show very high coefficient even higher in case of the new, never used oil. Boundary friction supposes that between the contact pair, considering the specimen test, the ball and the disc, just a a molecular boundary film is formed.

The reason behind the higher friction coefficient of new oil can be, that the base oil of the oil used during test (MOL Botond 20W50) is mineral oil. "In such raffinated mineral oils, carbohydrates, heterocyclic compounds can be found in small amount, from which a list of effective and dangerous properties arise. These compounds - that contain oxygen, sulphur or nitrogen represent antioxidant and boundary friction properties, but cause residuals, which worsens lubrication." [3] The other reason why the used oil provides better friction coefficient during boundary friction is, that solid lubricants such as lead residuals have self-lubricating properties and thus ensure low fricition coefficient. Lead can be present in this case as a contaminant from the fuel and during friction the generated heat or chemical reaction makes the lead attached to the sliding surface or blends with the oil. [7]

As a consequence, the worst quality of the newer oil can be a factor why the used oil performed better in the test. Oil viscosity and flowing properties degraded over the last few years because of the mass production and consumer society. We can state the the quality of the used oil, which is approximately 10-15 years old, was better.

The examination originates from what kind of effects the unleaded fuel has on the engine. We should mention, that because of the low milage of the vehicle, it is rarely fuelled up, so the new and old standard fuels are mixed in its fuel tank, leaded and unleaded fuels. This fact can give us explanation why the value of boundary fricition in case of used oil is lower.Many research works have been done over decades about the effects of using unleaded fuels instead of leaded one. These research works conclude that due to unleaded fuel, wear increases and the so-called valve recession occurs inside the engine. [8,9]
We have the oil samples in an external laboratory examined, it is clear from the analysis compiled by MOL Lub Ltd. Laboratory (see below), that the oil really contained huge amount of lead. Lead could get into the oil from the older fuel and also from the wear of the bearings of the crankshaft.

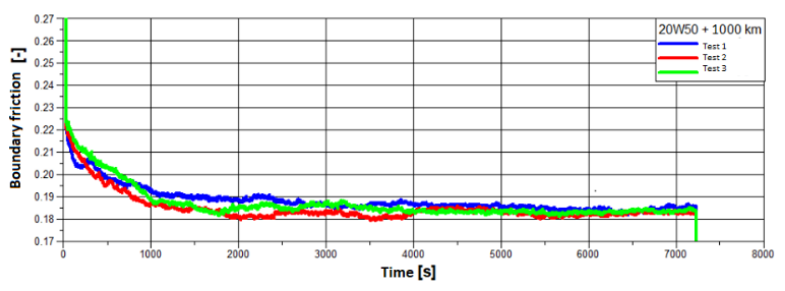

Figure 2: Diagram corresponding to the boundary friction with used oil $(1000 \mathrm{~km})$ in the measurement

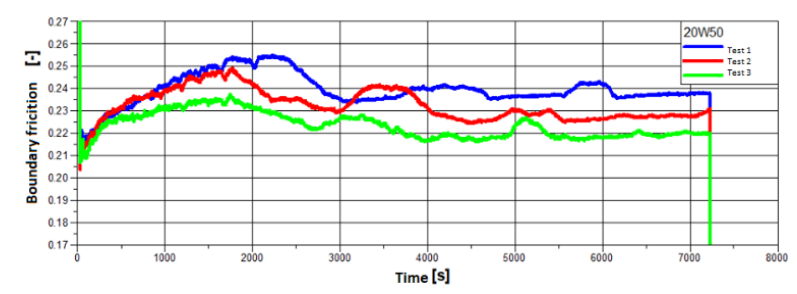

Figure 3: Diagram corresponding to the boundary friction with brand new oil $(0 \mathrm{~km})$ in the measurement

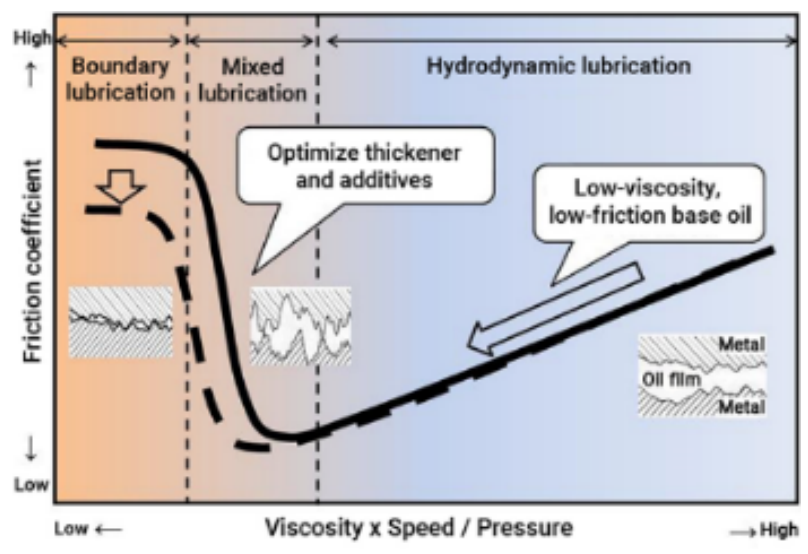

Figure 4: Stribeck curve (Source:

www.eneos.co.jp/english/company/rd/intro/lubricants/eco.h tml)

Stribeck curve helps us to evaluate the diagrams. This curve represents the friction coefficient as a function of the ratio of oil film thickness and surface roughness.

The $\lambda$ is the ratio of the intermediate medium and surface roughness. Boundary friction evolves if $\lambda<1$.

Stribeck curve represents the same, the less friction coefficient, the higher $\lambda$ is. As a consequence, it can be assumed, that lead functions as lubricant during the wear-model measurement. In case of the new $(\mathrm{km})$ oil, there is no evidence for lead in the oil coming from the fuel, so this case only oil is able to lubricate. That is the reason for the higher friction coefficient.

If we talk about boundary lubrication, friction happens in some kind of modification of the lubricant. The physical-, chemical state of the surfaces has significant role, additives in the lubricant or the pollutants, in this case lead, create a strong chemical sorption layer on the base metal [3]. 
In this case, lead worked as required before: it functioned as a solid lubricant. That is the reason why friction is more favourable in this system.

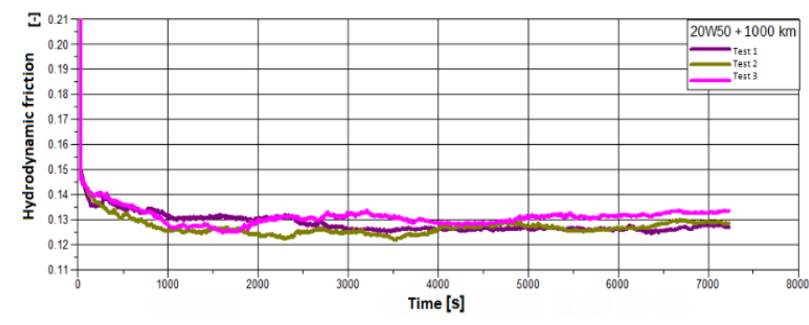

Figure 5: Diagram corresponding to the hydrodynamic friction with used oil $(1000 \mathrm{~km})$ in the measurement

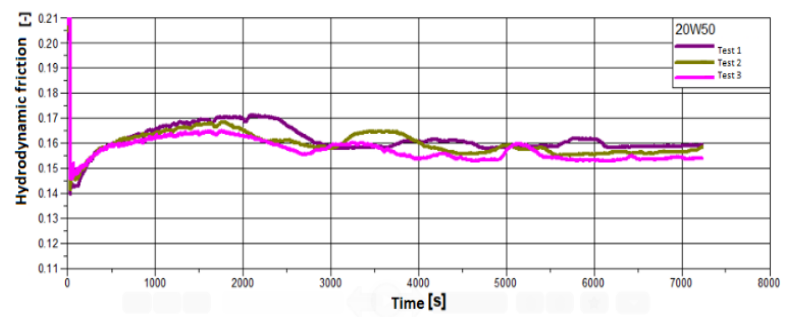

Figure 6: Diagram corresponding to the hydrodynamic friction with brand new oil $(0 \mathrm{~km})$ in the measurement

If $\lambda$ is greater than 3 in the Stribeck curve, we can talk about hydrodynamic friction. This type of friction means that between the two interacting surfaces, there formed a load-bearing film with proper thickness. If we observe the two figures (Figure 5, 6.) about the hydrodynamic friction values, we can assume that the used oil (ran $1000 \mathrm{~km}$ ) performed well in the measurement. In this case, we should make a comparison again with the new test results and the Stribeck curve. It is readable from the curve, that the greater the $\lambda$ value, the more the friction coefficient increases. We can interpret that, as the oil film thickness is greater in case of the new, bottled oil, this is readable from the diagram as well, there are higher friction values in the system. These higher values of the new oil can be due to the viscosity difference of the oils. The viscosity difference can come from conditions of the engine operation. Water condensation can degrade the quality of the engine oil, furthermore engine oil is not in a closed space and vapours can penetrate to it. Since these factors, viscosity decreased of the used oil and because of that, it could not remain on the lubricating surface during the test, thus friction coefficient remained low, the resistance of the oil was low due to low viscosity. Optimol SRV tribometer monitors the hydrodynamic friction conditions during the test, however the permanent temperature of the oil is $100^{\circ} \mathrm{C}$, which means its kinematic viscosity is $17,5 \mathrm{~mm}^{2} / \mathrm{s}$. It is assumable, that the system did not reach the hydrodynamic friction conditions during the tests due to the low viscosity of the oil and that is why the diagrams of boundary friction and hydrodynamic friction show similarities in values and shapes. Used oil could have better friction coefficient in this $100^{\circ} \mathrm{C}$, because at this temperate lead can penetrate to the surface and stick to the roughness peaks, so decreasing the resistance and friction between surfaces. The reason behind the behaviour of the oil during test is its type and the mineral base oil.
However, this does not mean that after performing the experiments on specimens, it is assumable that because of the lower friction coefficients, used oil behaves itself better in the engine. Diagrams made by the tribometer can lead us to draw such conclusions, that in case of model-examinations, oil ran $1000 \mathrm{~km}$ has better lubricating attributes than the new oil. Figure 7 includes the average of the measured values in a simplified diagram. This summarizes the diagrams shown before. New oil had higher friction coefficient values functioning as a lubricant, than the used oil. It is important to be aware the fact, that this is a modelexamination, processes inside the engine differ from that. Real conclusions may be drawn after the analysis of the microscopic pictures and the oil content.

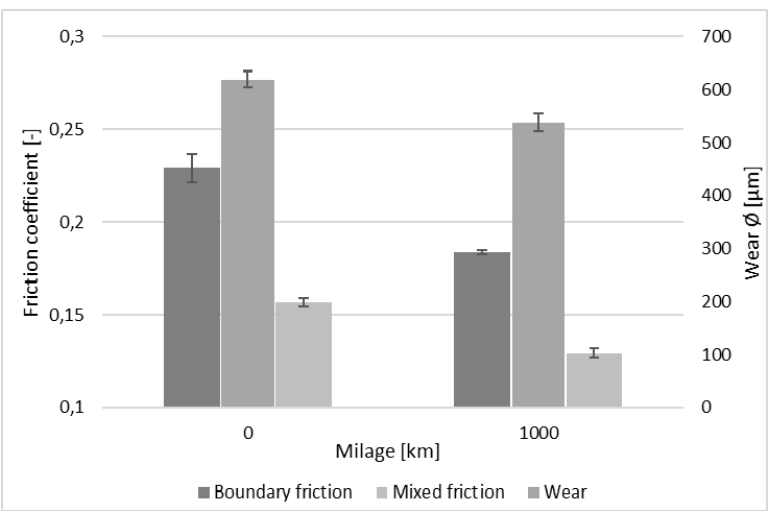

Figure 7: Friction coefficient represented as a function of the diameter of wear and milage

In case of the balls, we used $100 \times 200$ objective zoom, in case of the discs 100x100 zoom was used to create photos.

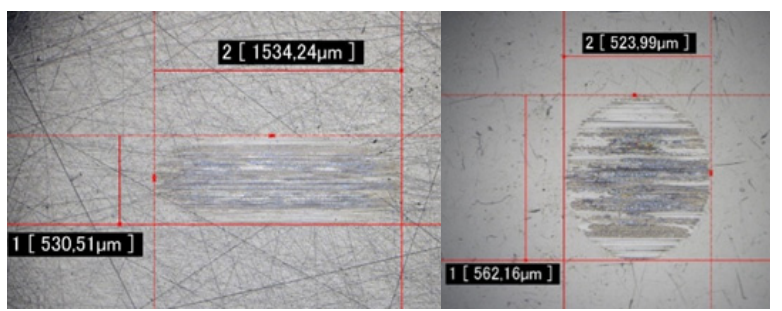

Figure 8: Wear photos of specimens used in the measurement with $1000 \mathrm{~km}$ ran, used oil: ball on the left and disc on the right

Considering Figure 8, we can assume, that in case of the oil, that run $1000 \mathrm{~km}$, there was little evidence for the presence of oil in the wear scar of the specimen, thus there were no surface protection by the oil. This verifies the theory that lead ensured the lubrication of the system as a solid lubricant. The shape of the wear is egg-shaped, and not a regular circle, so the wear is not ordinary. Those deeps scars in the pictures with white colour, parallel to the direction of the movement, are the evidence for strong abrasive wear.Oil disappeared from that area, where the contact and movement formed between the specimens. The reason behind this, is the significant fuel-content of the oil. Its viscosity decreased due to this. The flow characteristics of the oil changed, it became thinner. It was not able to stick on the surface, thus there was metal-to-metal friction. The wear scar is similar in case of the disc. The scar totally covers the original scars, made during manufacturing, in case of 
the new oil, this is different. This enables us to conclude, that the wear is much deeper in the first case. Thus, the scale of the scar is more severe in the point of view of the surface.

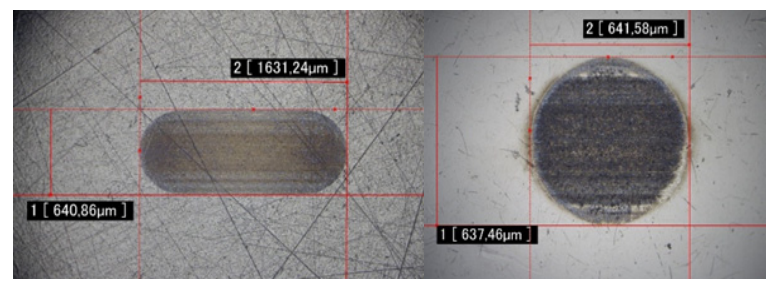

Figure 9:Wear photos of specimens used in the measurement with $\mathbf{0 ~ k m ~ r a n , ~ u s e d ~ o i l : ~ b a l l ~ o n ~ t h e ~ l e f t ~ a n d ~ d i s c ~ o n ~}$ the right

Figure 9 shows a smooth wear in case of the new oil. It is visible from the picture of the wear scar, that wear formed along with the centreline. This formation is not optimal in the point of view of the system. The outer part of the wear scar seems to be lighter, this means that wear formed in this area at the end of the measurement. This is not a significant problem in the point of view of the system, oil protected the surfaces. Wear scar represents a smooth and plain surface. Scratches are well visible under the wear scar in the wear figure, in case of the new oil less deep wear scar is detected. This allows us to conclude that in case of the new oil the wear is less significant and more favourable. Previously, we have mentioned that in cooperation with MOL Lub Ltd. oil diagnostic reports were carried out, after obtaining the results of oil content analysis. These reports give a comprehensive view of the changes in the oil conditions in case of the used and 1000 ran oil. Examination standards are included in the $5^{\text {th }}$ column of next tables. Main parameters are in the following tables.

\begin{tabular}{|l|l|c|c|l|}
\hline State of oil & & Used & New & Examination standard \\
\hline Kinematic viscosity, $40^{\circ} \mathrm{C}$ & $\mathrm{mm}^{2} / \mathrm{s}$ & 65 & 155 & ASTM D 7279-16 \\
\hline Kinematic viscosity, $100^{\circ} \mathrm{C}$ & $\mathrm{mm}^{2} / \mathrm{s}$ & 11,2 & 17,6 & ASTM D 7279-16 \\
\hline Index of viscosity & & 166 & 125 & ASTM D 2270-10(2016) \\
\hline OCI* & & 25 & 9 & MOL-LUB M-59:2007 \\
\hline Dispergence & & 97 & 100 & ASTM D 7899-13 \\
\hline Ba content & $\mathrm{mg} / \mathrm{kg}$ & $<1$ & $<1$ & ASTM D 5185-13e1 \\
\hline Ca content & $\mathrm{mg} / \mathrm{kg}$ & 1794 & 2113 & ASTM D 5185-13e1 \\
\hline Mg content & $\mathrm{mg} / \mathrm{kg}$ & 26 & 5 & ASTM D 5185-13e1 \\
\hline P content & $\mathrm{mg} / \mathrm{kg}$ & 743 & 789 & ASTM D 5185-13e1 \\
\hline Zn content & $\mathrm{mg} / \mathrm{kg}$ & 858 & 921 & ASTM D 5185-13e1 \\
\hline S content & $\mathrm{mg} / \mathrm{kg}$ & 3704 & 3348 & ASTM D 5185-13e1 \\
\hline B content & $\mathrm{mg} / \mathrm{kg}$ & 59 & 5 & ASTM D 5185-13e1 \\
\hline Mo content & $\mathrm{mg} / \mathrm{kg}$ & 6 & $<1$ & ASTM D 5185-13e1 \\
\hline
\end{tabular}

Figure 10: Table showing the comparison of the state of oils

Examination parameters in the $1^{\text {st }}$ column, units are in the $2^{\text {nd }}$, values belonging to the $1000 \mathrm{~km}$ ran, used oil are in the $3^{\text {rd }}$ column and values belonging to the new oil are in the $4^{\text {th }}$

First of all, the state of oil was examined, from which, the viscosity of the used oil turned out to be 2,5 times less than the viscosity of the new oil. The reason behind the decrease of viscosity is the significant amount of water and fuel in the oil.

Fuel can enter oil due to the engine operation and conditions. For instance, below operating temperature compression ring does not fit properly, a clearance appears between the piston and the cylinder wall or in case of infavourable enrichment, when petrol scavenges oil from the cylinder wall. This phenomenon can occur in case of older, worn engines even in operating temperature ranges. Another possibility considering the VAZ-2101 engine is the large-scale component wear due to unleaded fuel, as a result of which, these components do not seal properly [10-12]. Calcium (Ca), zinc $(\mathrm{Zn})$, phosphorus $(\mathrm{P})$ and sulphur $(\mathrm{S})$, found in the oil, are the elements of an additive. This additive is the so-called ZDDP compound containing zinc, phosphorus and sulphur. ZDDP was the most oftenly used oxidation inhibitor, corrosion resisting and wear reducing additive, because it worked perfectly under extreme temperature conditions and pressure as well. Todays's environmental categories it is not permitted to use in modern engine, because along with its numerous advantegous attributes, it has soot-forming effects and it damages the particulate filter. Considering vintage cars, harmful emissions may be kept in mind limitedly, since these are not up-to-date vehicles. In case of the examined engines, the usage of ZDDP has advantages in the point of view of the engines lifespan. It also turns out from the analysis, what kind of pollutants are in the oil coming from the engine, this can be read from Figure 11.

\begin{tabular}{|l|l|c|c|c|}
\hline Contamination & & Used & New & $\begin{array}{c}\text { Examination } \\
\text { standard }\end{array}$ \\
\hline Fuel content & grade & Warning & N & MOL-LUB M-58:2007 \\
\hline Water content & $\%$ & 0,25 & - & MOL-LUB M-60:2007 \\
\hline Coolant & grade & Negative & Negative & MOL-LUB M-66:2007 \\
\hline Soot content & $\%$ & 0,5 & 0 & ASTM D 7899-13 \\
\hline Na content & $m g / k g$ & 7 & $<1$ & ASTM D 5185-13e1 \\
\hline K content & $m g / k g$ & 7 & 1 & ASTM D 5185-13e1 \\
\hline Si content & $m g / k g$ & 30 & 2 & ASTM D 5185-13e1 \\
\hline Li content & $m g / k g$ & $<1$ & $<1$ & ASTM D 5185-13e1 \\
\hline
\end{tabular}

Figure 11: Table showing the comparison about pollutants found in oils

Examination parameters in the $1^{\text {st }}$ column, units are in the $2^{\text {nd }}$, values belonging to the $1000 \mathrm{~km}$ ran, used oil are in the $3^{\text {rd }}$ column and values belonging to the new oil are in the $4^{\text {th }}$

It is readable from the table above also, what we have previously mentioned, that the fuel and water content of the oil is significantly high. Both of the values are indicated with warning signal by the laboratory. Soot content of the used oil is also significant, which goes along with viscosity-increase effect, however the fuel and water content is so high, that it weakens this effect of the soot. Soot originates from the non-flammable materials remaining in the lubricant after combustion. We have mentioned the probable reasons behind the fuel content.

In case of these outdated, carburettor engines during cold-start the cold-start apparatus, also known as choke is inevitable to use. When using the choke, engine gets clean petrol during cold-start, with which, it can easily enter the oil circle through the cylinder wall, and thus the viscosity of the engine oil gets worse. Theoritically, the water content of the oil shows only a momentary value, because in case of the examined vehicle, the oil pan is relatively significant and so, large amount of water condenses on its walls because of warm-up and cool-down. By screwing the oil filler cap off, we can easily admit whether there is water in the oil. If there is 
emulsion in the cap, then water can be found in the oil. After checking this, we can state, that water originates from the condensation occurring in the oil pan, which evaporates from the system after running the engine, so practically during operation oil is weakened by fuel.

Sodium $(\mathrm{Na})$, potassium $(\mathrm{K})$, lithium $(\mathrm{Li})$ and silicon (Si) are present in the oil because of the natural metal content of mineral oils. However, silicon ( $\mathrm{Si}$ ) content is not only high due to the base oil's metal content, but also because of the wear of the journal bearings of the crankshaft. The significant wear of the bearings is also indicated by the warning signal by that parameter. The reason of this is mainly due to the corrosion of the bearing metal or abrasive wear, for instance from the agglomeration of particles in the oil filter. Unfortu-nately, majority of bearing malfunctions are from fatigue or abrasive wear and they cannot be avoided only with lubricants. Engine produces minimal wear even at optimal operational conditions, that can circulate in the oil.

\begin{tabular}{|l|l|c|c|l|}
\hline Wear & & Used & New & Examination standard \\
\hline Al content & $m g / k g$ & 34 & 1 & ASTM D 5185-13e1 \\
\hline Cr content & $m g / k g$ & $<1$ & $<1$ & ASTM D 5185-13e1 \\
\hline Cu content & $m g / k g$ & 20 & $<1$ & ASTM D 5185-13e1 \\
\hline Fe content & $m g / k g$ & 353 & $<1$ & ASTM D 5185-13e1 \\
\hline Mn content & $m g / k g$ & 11 & $<1$ & ASTM D 5185-13e1 \\
\hline Ni content & $m g / k g$ & $<1$ & $<1$ & ASTM D 5185-13e1 \\
\hline Pb content & $m g / k g$ & 8 & $<1$ & ASTM D 5185-13e1 \\
\hline Sn content & $m g / k g$ & $<1$ & $<1$ & ASTM D 5185-13e1 \\
\hline Ag content & $m g / k g$ & $<1$ & $<1$ & ASTM D 5185-13e1 \\
\hline Ti content & $m g / k g$ & $<1$ & $<1$ & ASTM D 5185-13e1 \\
\hline V content & $m g / k g$ & $<1$ & $<1$ & ASTM D 5185-13e1 \\
\hline
\end{tabular}

Figure 12: Table showing the comparison about contaminants found in oil

Examination parameters in the $1^{\text {st }}$ column, units are in the $2^{\text {nd }}$, values belonging to the $1000 \mathrm{~km}$ ran, used oil are in the $3^{\text {rd }}$ column and values belonging to the new oil are in the $4^{\text {th }}$

Figure 12 represents the evaluation about wear, in which, iron is indicated with red warning signal. Iron is the material of engine timing components.

Lead content of the oil contributed to the optimal friction coefficient during fluid friction as a secondary lubricant. The so-called secondary lubrication effect can appear in this case, when the soft solid lubricant, thus lead, is stored in textures of the surfaces in contact and it improves the lubricating conditions of the system. $[13,14]$

The most common forms of the rocker arm wear, are the indentation of camshaft and rocker arms and/or pitting, which originate from adhesive, abrasive or corrosive or fatigue wear. [3]

Aliminum can come from the cylinder head, camshaft housing and the piston, which happens even during the normal operation of the engine. The quality of engine oil has a crucial role in this issue.

The wear of the crankshaft and the connecting rod, moreover the main bearings are proven by lead, copper and manganese content of the oil, since these materials were used in older type vehicles' bearings. Wear of bearings is a natural process due to their load-bearing role.

\section{CONCLUSIONS}

It is obvious from the laboratory measurements and analyses, what kind of negative effects unleaded fuel has on the engine. Our first recommendation is to reduce the oil change period in case of vintage vehicles, since depending on the conditions of the engine, some amount of wear is always generated during operation. If this period is overly elongated, then too much pollutants agglomerate in the lubricating system, which leads to severe wear or malfunctions after reaching the engine component. Annually or 2000 kilometric oil change is advisable to be carried out, since the quality of engine oil degrades. Its viscosity worsens by aging, water content from air also contributes to its viscosity decrease and quality degradation.

Furthermore, choosing the appropriate oil is the most important in the point of view of the engine. Generally, it is recommended to comply with the factory instructions, so for the case of these vehicles 40 or 50 single grade oils are given.

However, thank to modern, developed industry, there are engine oils designed especially for vintage vehicles.

It is worth purchasi premium quality oils, manufacturers suggest SAE classified oils according to year of production and additional features, in this case it is usually 15 W40 and 20W50 engine oils.

It is inevitable to use high viscosity, multigrade engine oils in vintage vehicles. Lubricating systems of older type cars are designed in a way that oil is transported in vertical channels, that is finally arrives to a helical tooth gear or to a crossing shaft.

By the usage of low viscosity oil, it would be splashed from the gear that would result in the inappropriate lubrication of the lubricating areas nearby. [15]

Older type oil pumps have lower performance than modern ones. Low viscosity oils do not seal these oldtype pumps properly, thus significant pressure- and volumeloss appear during operation. As a consequence, the oil consumption of the vehicle increases. If the oil consumption increases, then the vehicle burns the oil, which can enter the fuel due to the inproper sealing of piston-cylinder.

To keep the engine wear at a minimum value, socalled lead replacement petrol additives can be used. However, this has to be added into the tank while every refuelling. If this does not happen, in a short run nothing is sensible in operation, since the scale of wear is not visible. Its effect is only detectable after long-term, which's consequence is that the cylinder head needs reparation, or in extreme conditions, it has to be exchanged.

The additive itself, includes lead replacement material and it carries out lubrication in a similar manner as lead in fuel previously. The most accessible way to increase the lifetime of vintage cars is the restoration of the cylinder head. In the course of the cylinder head restoration, valve grinding, valve seat cutting and cylinder head resurfacing are included. Modern fuels contain huge amount of alcohol, that damages the rubber-made components. These parts need 
to be changed to new ones during restoration. It is also advisable to place a hardened, solid insert to the valve seat. This process requires high precision, since the most crucial part is the material option, because the casted block was not designed to this purpose originally, a not appropriate insert can slip out of the seat.

\section{REFERENCES}

[1] Tamás György- Virágh Iván: Hogyan tovább? Zsiguli/Lada, Müszaki Könyvkiadó, Budapest, 1984, 290

[2] Technical data sheet of MOL Botond 20W50 multigrade engine oil

[3] Dr.ValasekIstván: Tribológiaikézikönyv, TribotechnikKft., 1996, 230-250

[4] International Organization for Standardization, Lubricants - Determination of tribological quantites for oils and greases - Tribological test in the translatory oscillation apparatus, ISO 19291, 2016

[5] Technical data sheet of Optimol SRVC5 Basic oscillation system

[6] TóthÁlmos, SzabóÁdám, KutiRajmund: Tribological Poperties of Nano-Sized $\mathrm{ZrO} 2$ Ceramic Particles in Automotive Lubricants, FME Transactions 49 pp. 36-43, 2021

[7] Seiichro Hironaka: Boundary Lubrication and Lubricants, Three Bond Technical News, 1984

[8] Weaver, C. S.: The Effects of Low-Load and Unleaded Fuels Gasoline Engines. SAE Technical Paper Series, 1986

[9] W. W. Crouse, R. H. JohnsonW. H. Reiland: Effect of Unleaded Fuel on Lubricant Performance, International Mid-Year Meeting, 1971

[10] Willam Giles: Valve Problems with lead free gasoline, SAE International, 1971
[11] William S. Giles, Staley H. Updike: Influence of low lead fuels on exhaust valve performance, SAE International, 1971

[12] Gary A. Schoonveld, Richard K. Riley, Stephen P. Thomas, S. Schiff: Exhaust valve recession with low-lead gasolines, SAE International, 1998

[13] Dinghuai Yang1, and Junjie Zhang: The Secondary Lubrication Effect under Fluid Lubrication, DEStech Transactions on MATERIALS SCIENCE and ENGINEERING, 2020

[14] Azmi. Roslan, Ahmmed. S. Ibrahem, and Abdul Hadi: Metal additives composition and its effect on lubricant characteristic, AIP Conference Proceedings 1774, 2016

[15] Understanding veteran, vintage and classic - Technical article by Penrite oil, 2015 November

\section{УТВРЪИВАЊЕ ОШТЕЋЕЊА МОТОРА КОД ВИНТИЏ ВОЗИЛА ТРИБОЛОШКИМ ИСПИТИВАЊЕМ}

\section{Ц. Пап, Р. Кути}

Данас је све популарније одржавање винтиџ возила у возном стању, али је поправка неисправности мотора и набавка одређених делова веома скупа. Код старијих мотора откази се не детектују компјутерском дијагностиком. У више случајева отказ је могуће утврдити само расклапањем мотора. Исплативо решење могла би бити примена триболошких испитивања којима се лако могу открити неисправности без потребе за расклапањем мотора. Рад приказује практично решење проблема код возила VAZ-2101 (познатог под именом Lada) применом триболошке методе, анализе података, евалуације резултата и фаза детекције отказа. 